\title{
Assessment of in vitro methodologies to determine topical and transdermal delivery of the flavonoid quercetin
}

\author{
Fabiana Testa Moura de Carvalho Vicentini, Sandra Regina Georgetti, Maria Vitória Lopes Badra \\ Bentley, Maria José Vieira Fonseca*
}

Department of Pharmaceutical Sciences, Faculty of Pharmaceutical Sciences of Ribeirão Preto, University of São Paulo

\begin{abstract}
To be effective against the oxidative damages induced by UVB irradiation in the skin, the drug needs to release from the formulation in which it was incorporated and reach the skin layers where the ROS are generated. Thus, it is very important the development of a robust and sensitive methodology to extract and quantify in different skin layers the antioxidant agent delivered from topical formulations. Therefore, in the present work suitable methods to extract and quantify quercetin in skin samples and receptor phase after in vitro penetration studies were developed. The results demonstrated that the recovery from two different layers of skin, the SC and [E+D], using two different methods of quantification (DPPH ${ }^{\bullet}$ assay and HPLC, respectively), was $93.8 \%$ when the quercetin spiked dose was $50 \mu \mathrm{g} / \mathrm{mL}, 100.4 \%$ when it was $100 \mu \mathrm{g} / \mathrm{mL}$ and $89.9 \%$ for $250 \mu \mathrm{g} / \mathrm{mL}$ and the average recovery of the quercetin extraction from receptor phase when dichloromethane was used as extractor solvent was $96 \%$. These results demonstrate that the described methods have a potential application to in vitro skin penetration studies of quercetin, since it showed to be accurate and sensitive.
\end{abstract}

Uniterms: Topical formulations/analysis. Quercetin/quantification. Quercetin/extraction. Quercetin/ liberation. Skin penetration in vitro/study. High performance liquid chromatography. DPPH ${ }^{\bullet}$.

Para ser efetiva contra os danos oxidativos induzidos pela radiação UVB na pele, é necessário que o ativo seja liberado da formulação na qual foi incorporado e alcance as camadas da pele onde são geradas as EROS. Desta forma, torna-se de grande importância o desenvolvimento de métodos eficazes e sensíveis para extrair e quantificar, nas diferentes camadas de pele, o agente antioxidante liberado de formulações tópicas. No presente trabalho foram desenvolvidos métodos adequados para extrair e quantificar a quercetina em amostras de pele e na fase receptora após estudos de penetração cutânea in vitro. Os resultados demonstraram que a recuperação das camadas de pele, EC e [E+D], quando do uso de duas diferentes metodologias de quantificação (ensaio de DPPH• e CLAE, respectivamente), foi de 93,8 \% quando aplicada uma dose de $50 \mu \mathrm{g} / \mathrm{mL}$ de quercetina, $100,4 \%$ para $100 \mu \mathrm{g} / \mathrm{mL}$ e $89,9 \%$ para $250 \mu \mathrm{g} / \mathrm{mL}$ e a recuperação média da extração da quercetina da fase receptora, quando do emprego de diclorometano como solvente extrator, foi de $96 \%$. Tais resultados demonstram que os métodos descritos têm grande potencial de aplicação em estudos de penetração in vitro já que apresentaram exatidão e sensibilidade.

Unitermos: Formulações tópicas/análise. Quercetina/quantificação. Quercetina/extração. Quercetina/ liberação. Penetração cutânea in vitro/estudo. Cromatografia líquida de alta eficiência. DPPH•.

\section{INTRODUCTION}

Skin is the largest human organ, and is the only organ directly exposed to ultraviolet (UV) irradiation. Chronic exposure to UV irradiation causes premature skin aging,

\footnotetext{
*Correspondence: M. J. V. Fonseca. Departamento de Ciências Farmacêuticas. Faculdade de Ciências Farmacêuticas. Universidade de São Paulo - Ribeirão Preto. Av. do Café, s/n - 14040-903 - Ribeirão Preto, SP, Brazil. E-maildress:magika@fcfrp.usp.br
}

local and systemic immunosuppression, decrease in the skin antioxidant defence and ultimately photocarcinogenesis (Boudjelal et al., 2000; Xu, Fisher, 2005). Reactive oxygen species (ROS) are implicated in UV-light induced damage to skin and could be an initiator in the pathogenesis of skin cancer and photoaging (Podda et al., 1998).

Therefore, considering that few tissues in the body are subjected to similar degrees of oxidative stress exposure, it has been suggested the beneficial effect of topical antioxidant, which might be a successful strategy for di- 
minishing UV radiation-mediated oxidative damage of the skin. In this context, recently work has demonstrated the beneficial effectiveness of topical formulations containing quercetin, a flavonoid which has well-known antioxidant activity, in inhibiting the oxidative stress and inflammation induced by UVB irradiation (Casagrande et al., 2006a).

Nevertheless, the primary requirement for topical therapy is that a drug incorporated into a vehicle reach the skin surface and penetrates at an adequate rate and in sufficient amount (Röpke et al., 2002). Then, the evaluation of topical absorption of quercetin becomes a crucial step in studies suggesting the possible use of this flavonoid in topical formulations. This evaluation also requires the development of a robust and sensitive method to extract and quantify this drug in the skin, in order to predict if adequate amounts of drug were delivered from the formulation and reach viable layers of skin, where the ROS are generated.

Casagrande et al. (2007) proposed the use of the measurement of antioxidant activity as an efficient approach to evaluate quercetin skin retention. Nevertheless, the recovery obtained when this methodology is employed was not evaluated.

Therefore, one of the objectives of the present study was the development of simple and accurate methods to extract quercetin from stratum corneum (SC) and epidermis (E) plus dermis (D) ([E+D]) of porcine ear skin, quantifying the drug in homogenates of these skin layers using the previous validated methods: DPPH ${ }^{\bullet}$ and HPLC, respectively.

Considering that different studies have demonstrated the poor quercetin ability to permeate through excised human and porcine skin and that it has been proposed the topical use of this flavonoid to control UVB-induced oxidative skin damages (Casagrande et al., 2007; Saija et al., 1998), it is important to develop a sensitive methodology to extract and determine very small amounts of this drug which might permeate through skin and also to assure, when a topical formulation is used, that all the drug applied was retained in the skin. Therefore, this work aimed also to develop a simple, reproducible and sensitive method to extract and quantify quercetin from receptor medium.

\section{MATERIAL AND METHODS}

\section{Chemicals and reagents}

Quercetin dihydrate $99 \%\left(\mathrm{C}_{15} \mathrm{H}_{10} \mathrm{O}_{7} \cdot 2 \mathrm{H}_{2} \mathrm{O}, \mathrm{M}_{\mathrm{w}}=\right.$ 338.26) was purchased from Acros Organics (New Jersey, USA), propylene glycol and polyoxyethylene (20) sorbitan monolaurate (Tween ${ }^{\circledR} 20$ ) from Synth (Diadema,
SP, Brazil), and 2,2-diphenyl-1-picryl-hydrazyl (DPPH) from Sigma Chemical Co. (St. Louis, MO, USA). All used organic solvents were HPLC grades and provided by J.T.Baker (USA) and Merck (Darmstadt, Germany). All other chemicals were of reagent grade and were used without further purification.

\section{Skin preparations}

Briefly, the skin from the outer surface of a freshly excised porcine ear was carefully dissected and dermatomized, stored at $-20^{\circ} \mathrm{C}$, and used within a month.

\section{Quercetin recovery from porcine skin}

The absolute recovery of quercetin from skin tissue was determined adding $200 \mu \mathrm{L}$ of methanolic quercetin solutions $(50,100$ and $250 \mu \mathrm{g} / \mathrm{mL}$ ) in skin sections (area of $1.77 \mathrm{~cm}^{2}$ ). These spiked skin sections ( $\mathrm{n}=3$ for each concentration) were allowed to rest for 20 minutes. Quercetin was assessed in two different skin layers: SC and $[\mathrm{E}+\mathrm{D}]$. To separate the $\mathrm{SC}$ from the remaining $[\mathrm{E}+\mathrm{D}]$, skin sections were subjected to tape stripping. The tape stripping technique is being increasingly used to measure drug concentration and its concentration profile across the stratum corneum (Moser et al. 2001). This skin layer was stripped with 15 pieces of adhesive tape, which were immersed in $4 \mathrm{~mL}$ methanol, vortex stirred for $1 \mathrm{~min}$, bath sonicated for $15 \mathrm{~min}$ and the methanolic phase filtered using $0.45 \mu \mathrm{m}$ membrane. The evaporated filtrate residue was suspended in $500 \mu \mathrm{L}$ of methanol and quercetin was assayed by measuring its antioxidant activity by the $\mathrm{DPPH}^{\bullet}$ assay, as described below.

The remaining $[\mathrm{E}+\mathrm{D}]$ were cut in small pieces, vortex mixed for $2 \mathrm{~min}$ in $4 \mathrm{~mL}$ of methanol, and bath sonicated for $30 \mathrm{~min}$. The resulting mixture was then filtered using a $0.45 \mu \mathrm{m}$ membrane, and quercetin was assayed in the filtrate by HPLC method as described below. The absolute recovery of quercetin extracted from skin layers was determined considering the sum of quercetin quantities in both skin layers $(\mathrm{SC}+[\mathrm{E}+\mathrm{D}])$.

The same experiments were also done by adding $200 \mu \mathrm{L}$ of quercetin solutions in methanol $(50,100$ and $250 \mu \mathrm{g} / \mathrm{mL}$ ) in skin sections having its SC previously removed by the tape stripping procedure, in order to determine the recovery percentage only of quercetin extracted from $[\mathrm{E}+\mathrm{D}]$.

\section{Quercetin recovery from receptor phase}

In order to identify a suitable receptor medium for in 
vitro experiments, the saturation solubility of quercetin in different media was analyzed. Three media were tested: (i) $0.15 \mathrm{M}$ phosphate buffer ( $\mathrm{pH} 7.2$ ), (ii) $0.15 \mathrm{M}$ phosphate buffer (pH 7.2) plus $10 \%$ of ethanol and (iii) $0.15 \mathrm{M}$ phosphate buffer ( $\mathrm{pH} 7.2$ ) plus $0.5 \%$ of polyoxyethylene (20) sorbitan monolaurate (Tween ${ }^{\circledR} 20$ ). An excess of quercetin was added to the media at $37^{\circ} \mathrm{C}$ and stirred for $12 \mathrm{~h}$. After filtering (Millex LCR filter $0.45 \mu \mathrm{m}$ ), the quercetin content was analyzed by HPLC method (Casagrande et al., 2007; Saija et al., 1998).

To determine the recovery of quercetin from receptor phase this drug was extracted from selected receptor medium $(0.15 \mathrm{M}$ phosphate buffer, $\mathrm{pH} 7.2$ plus $0.5 \%$ of Tween ${ }^{\circledR} 20$ ) by liquid-liquid extraction method using the organic solvents hexane, dichloromethane and chloroform.

For this analysis it was prepared quercetin solutions in $0.15 \mathrm{M}$ phosphate buffer, $\mathrm{pH} 7.2$ plus $0.5 \%$ of Tween ${ }^{\circledR}$ 20 in the concentrations of $0.05,0.1,0.5,1.0,2.0$ and $5.0 \mu \mathrm{g} / \mathrm{mL}$. Five hundred microlitres of each solution were withdrawn and quercetin was extracted from each sample using $3 \mathrm{~mL}$ of extractor solvent. After the organic phase was evaporated, the residue was suspended in $100 \mu \mathrm{L}$ of a methanol: water $(60: 40 \mathrm{v} / \mathrm{v})$ mixture containing $2 \%$ acetic acid, and quercetin was assayed by HPLC as described below.

After the selection of the best solvent extractor, it was evaluated the recovery of quercetin after the extraction process. The recovery $(\mathrm{R})$ was determined using the formula below and the obtained concentration determined by using the regression equation of quercetin analytical curve:

Recovery $(\mathrm{R})=($ obtained concentration $/$ real concentration) $\mathrm{x} 100$

Since the recovery obtained was not satisfactory, the $\mathrm{pH}$ of $0.15 \mathrm{M}$ phosphate buffer, $\mathrm{pH} 7.2$ plus $0.5 \%$ of Twe$\mathrm{en}^{\circledR} 20$ solution containing quercetin was altered to 4.0, 5.0 and 8.6 and after being selected the most appropriate one, all the extraction proceedings and recovery analysis were done again.

In order to evaluate the effectiveness of the solvent drying procedure, it was prepared methanolic quercetin solutions at the same concentrations, in the range of 0.05-5.0 $\mu \mathrm{g} / \mathrm{mL}$, and the extraction stage was omitted. For this, appropriate volumes of methanolic quercetin solutions were evaporated and the residue was suspended in $100 \mu \mathrm{L}$ of a methanol: water $(60: 40 \mathrm{v} / \mathrm{v})$ mixture containing $2 \%$ acetic acid, being quercetin then assayed by HPLC method. The quercetin recovery after the solvent drying procedure was evaluated as described above.

\section{In vitro skin penetration and percutaneous delivery}

The methodology developed for quercetin quantification in porcine skin was used to determine quercetin skin penetration after in vitro cutaneous penetration and percutaneous delivery experiments. On the day of the experiment, the skin was thawed and mounted on a Franz diffusion cell (diffusion area of $1.77 \mathrm{~cm}^{2}$; Hanson Instruments, Chatsworth, CA), with the SC facing the donor compartment (where the formulation was applied) and the dermis facing the receptor compartment. The latter compartment was filled with $150 \mathrm{mM}$ phosphate buffer (pH 7.2) containing Tween ${ }^{\circledR} 20$ (0.5\%). The receptor phase was under constant stirring and maintained at $37 \pm 0.5^{\circ} \mathrm{C}$.

One hundred milligrams of a solution composed of quercetin at $0.3 \%(\mathrm{w} / \mathrm{w})$ in propylene glycol $(\mathrm{n}=5)$ and a w/o microemulsion containing quercetin in the same final percentage $(n=5)$ were applied to the surface of the stratum corneum.

At $12 \mathrm{~h}$ post-application, skin surfaces were thoroughly washed with distilled water and wiped with a cotton swab to remove excess formulation. Quercetin was extracted from SC, $[\mathrm{E}+\mathrm{D}]$ and from receptor phase using the methodologies described above. The amounts of quercetin detected in $\mathrm{SC}$ and in $[\mathrm{E}+\mathrm{D}]$ are indicative of its penetration in the skin, whereas the amount in the receptor phase is indicative of its percutaneous delivery.

\section{Analytical methodology for quercetin}

\section{HPLC method}

HPLC analyses were used to determine quercetin concentration in the $[\mathrm{E}+\mathrm{D}]$ and receptor phase (transdermal delivery) and to identify a suitable receptor medium for quercetin. The HPLC apparatus consisted of a Shimadzu (Kyoto, Japan) liquid chromatograph system, equipped with an LC-10 AT VP solvent pump unit and an SPD-10A VP UV-Visible detector. Samples were injected manually through a $20 \mu \mathrm{L}$ loop with a Rheodyne injector. The separation was performed in a C18 Hypersyl BDSCPS ciano $(5 \mu \mathrm{m}), 250 \times 4.6 \mathrm{~mm}$ column with a mobile phase of methanol: water $(60: 40 \mathrm{v} / \mathrm{v})$ containing $2 \%$ acetic acid (flow rate of $1 \mathrm{~mL} / \mathrm{min}$ ) and quercetin detected at $254 \mathrm{~nm}$. Data were collected using a Chromatopac CR8A integrator (Shimadzu, Kyoto, Japan).

\section{Antioxidant activity by the DPPH• assay}

Stratum corneum quercetin was measured by its antioxidant activity in the $\mathrm{DPPH}^{\bullet}$ assay due to HPLC lack of selectivity. 
The quercetin H-donor ability was evaluated using an ethanol solution of $\mathrm{DPPH}^{\circ}$, a stable nitrogen-centered free radical. Briefly, for radical scavenging measurements, $1 \mathrm{~mL}$ of $0.1 \mathrm{M}$ acetate buffer (pH 5.5), $1 \mathrm{~mL}$ of ethanol and $0.5 \mathrm{~mL}$ of $250 \mu \mathrm{M}$ ethanolic solution of $\mathrm{DPPH}^{\bullet}$ were mixed with $50 \mu \mathrm{L}$ of the test sample and the light absorbance measured after $10 \mathrm{~min}$ at $517 \mathrm{~nm}$ (Blois, 1958; Dinis et al., 1994). Positive control was prepared using control skin sections (untreated), which indicated the maximum odd $\mathrm{DPPH}^{\bullet}$ electrons, considered as $100 \%$ free radicals in the solution and used to calculate the hydrogen-donating ability of quercetin (\%). To determine SC extracted quercetin, the $\% \mathrm{H}$-donating ability was transformed in quercetin concentrations $(\mu \mathrm{g} / \mathrm{mL})$ using the regression equation obtained by plotting concentrations of quercetin against hydrogen-donating ability (\%) for each concentration. The blank was prepared from the reaction mixture without $\mathrm{DPPH}^{\bullet}$ solution and all measurements were performed in triplicate.

\section{RESULTS AND DISCUSSION}

The beneficial effect of the use of topical antioxidants, such as the flavonoid quercetin, in order to reduce UV radiation-mediated oxidative damage of the skin has been suggested (Casagrande et al., 2006a; Saija et al., 1998). Nevertheless, suitable percutaneous absorption is known to be an essential requirement for satisfactory topically applied photoprotective agents (Bonina et al., 1996; Saija et al., 1998). Although Casagrande et al. (2007) had suggested an efficient approach to evaluate the quercetin skin retention released from topical formulations, the recovery of the proposed methodology was not evaluated and to date, no study was aimed to develop a robust and sensitive method to extract and quantify quercetin from different skin layers.

The HPLC method has been widely used to separate and quantify flavonoids presents in plants and foods (Careri et al., 2000; Saija et al., 1998). Previous work of our group demonstrated the precision and accuracy of the chromatographic method developed for the quantitative determination of quercetin. Values obtained with standard methanolic quercetin solutions showed linearity over the concentration range of 0.1 to $200 \mu \mathrm{g} / \mathrm{mL}$ with a correlation coefficient (r) of 0.999 . The quantification limit in the HPLC assay was $0.03 \mu \mathrm{g} / \mathrm{mL}$ and the average for relative standard variation and error was no more than $4.68 \%$ in all concentrations tested, which is considered adequate for analytical assay (Vicentini et al., 2007b).

Firstly, the selectivity of this HPLC-UV method was verified by evaluating the interference of compounds from skin and from the adhesive tape on the assay of quercetin. Figure 1 shows chromatogram of $[\mathrm{E}+\mathrm{D}]$ homogenates from control skin sections and demonstrates that the compounds of skin did not interfere with the analysis of quercetin. Nevertheless, the adhesive tape used for the tape stripping procedure caused interference, some compound present in the adhesive tape showed similar retention time to that obtained for quercetin, when analyzed under the same chromatographic conditions. Then, the HPLC method proposed was selective only for the evaluation of the quercetin present in the $[\mathrm{E}+\mathrm{D}]$. Therefore, the $\mathrm{DPPH}^{\circ}$ assay was used as an alternative approach to evaluate the possible retained quercetin in the SC.

$\mathrm{DPPH}^{\bullet}$ is a stable free radical that can accept an electron or hydrogen radical converting into stable, diamagnetic molecule. Because of its odd electron, $\mathrm{DPPH}^{*}$ has a strong absorption band at $517 \mathrm{~nm}$. As this electron becomes paired off, the absorption decreases stoichiometrically with respect to the number of electrons taken up. Such a change in absorbance produced in this reaction has been widely used to test the ability of several molecules to act as free radical scavengers (Dinis et al., 1994).

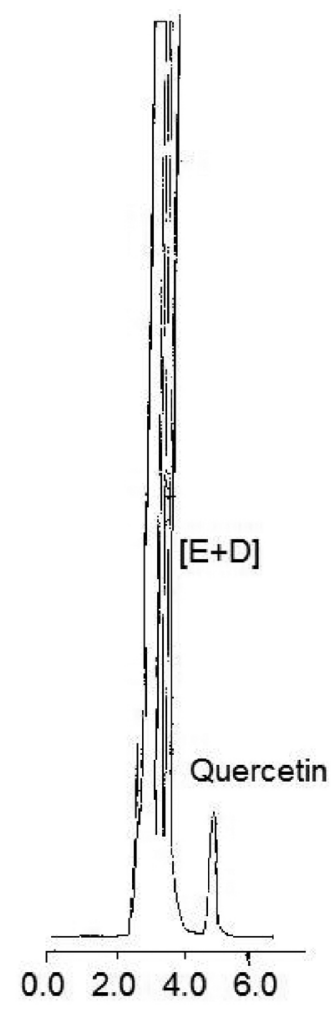

FIGURE 1 - Chromatogram of [E+D] homogenates compared to the profile of a $5 \mu \mathrm{g} / \mathrm{mL}$ quercetin solution. Chromatographic conditions: C18 Hypersyl BDS-CPS ciano $(5 \mu \mathrm{m}), 250 \mathrm{x}$ $4.6 \mathrm{~mm}$ column - attached to a pre column, mobile phase: methanol: water $(60: 40 \mathrm{v} / \mathrm{v})$ containing $2 \%$ acetic acid, $1 \mathrm{~mL} /$ $\min$. Detection at $254 \mathrm{~nm}$. 
Quercetin antioxidant activity has been demonstrated by different in vitro methods such as lipid peroxidation induced by $\mathrm{Fe}^{2+} /$ citrate (Casagrande et al., 2006b; Vicentini et al. 2007a), chemiluminescence using $\mathrm{H}_{2} \mathrm{O}_{2} /$ luminol/HRP system (Georgetti et al., 2003; Vicentini et al., 2007a) and $\mathrm{DPPH}^{\bullet}$ assay (Pinelo et al., 2004; Silva et al., 2002; Tsimogiannis, Oreopoulou, 2004; Vicentini et al., 2007a). The last one was chosen to be used in the analysis of quercetin retained in $\mathrm{SC}$ because besides to be an easy, inexpensive, fast and precise methodology to measure the antioxidant activity (Nuutila et al. 2003), the validation of this method, using methanolic solutions of quercetin showed its sensitivity, adequacy and reproducibility to measure the antioxidant activity of this flavonoid (Vicentini et al., 2007b). Furthermore, in the present work it was evaluated the skin components and adhesive tape interference in the detection of quercetin antioxidant activity using this methodology and the results showed that $\mathrm{DPPH}^{\bullet}$ assay is a selective method to analyze the quercetin present in the SC (data not shown). Therefore, the $\mathrm{DPPH}^{*}$ assay was used to determine the amount of quercetin in SC and HPLC was used to quantify the amount of this flavonoid in $[\mathrm{E}+\mathrm{D}]$.

The recovery percentage of quercetin extracted from skin layers $(\mathrm{SC}+[\mathrm{E}+\mathrm{D}])$ and only $[\mathrm{E}+\mathrm{D}]$ was showed in Table I. By comparing the results obtained by Lopes and Bentley (2005) in terms of cyclosporine recovery from skin layers, the use of the same methodologies was more efficient in the recovery of quercetin. Thus, these high recoveries obtained for different concentrations demonstrate that the methods for quercetin extraction and quantification in different skin layers, described in the present study, were very suitable to be employed on cutaneous penetration studies. Furthermore, the determi- nation of the retained quercetin in the SC by measuring its antioxidant activity showed to be an important and reliable alternative.

Casagrande et al. (2007) and Saija et al. (1998) demonstrated that quercetin did not permeate when different vehicles containing this flavonoid were topically applied. Nevertheless, it has been suggested that using a different approach it might be possible to detect quercetin in the receptor medium (Casagrande et al., 2007). Therefore, the development of a reliable method to extract and quantify the quercetin present in the receptor medium is very important to determine the possible permeation of this flavonoid and also to assure, if a topical formulation is applied, that no quercetin permeates through the skin.

First of all, the optimal receptor medium was selected. The selection of the receptor solution is an important decision to create in vitro conditions, which can adequately replicate the in vivo conditions. The receptor solution has an important influence on the in vitro absorption of compounds with low aqueous solubility such as quercetin. Solubilizers are commonly used to increase the solubility of drugs in the receptor solution, to assure sink conditions without apparent damage to skin. As a general rule, the concentration of the permeant should not be allowed to exceed $10 \%$ of saturation solubility (Casagrande et al., 2007; Moser et al., 2001). Therefore, in the present study, phosphate buffer $(\mathrm{pH} 7.2 ; 0.15 \mathrm{M})$ containing Tween ${ }^{\circledR} 20(0.5 \%)$, in which quercetin has a solubility of $27.93 \pm 0.26 \mu \mathrm{g} / \mathrm{mL}$ (Table II) was selected to be used as receptor phase.

Since it is well known the poor ability of quercetin to permeate the skin, the development of a robust and sensitive method to extract and quantify this flavonoid from the receptor medium is essential in the analysis of topical

TABLE I - Recovery of quercetin extracted from different skin layers

\begin{tabular}{ccccc}
\hline $\begin{array}{c}\text { Concentration added } \\
\left(\mu \mathrm{g} / \mathrm{cm}^{2}\right)\end{array}$ & $\begin{array}{c}\text { Concentration found } \\
(\mathrm{SC}+[\mathrm{E}+\mathrm{D}]) \\
(\mathrm{mean} \pm \mathrm{SD})\left(\mu \mathrm{g} / \mathrm{cm}^{2}\right)\end{array}$ & $\begin{array}{c}\text { Recovery }(\%) \\
(\mathrm{SC}+[\mathrm{E}+\mathrm{D}])\end{array}$ & $\begin{array}{c}\text { Concentration found } \\
([\mathrm{E}+\mathrm{D}]) \\
(\text { mean } \pm \mathrm{SD})\left(\mu \mathrm{g} / \mathrm{cm}^{2}\right)\end{array}$ & $\begin{array}{c}\text { Recovery }(\%) \\
([\mathrm{E}+\mathrm{D}])\end{array}$ \\
\hline 5.65 & $5.30 \pm 0.53$ & 93.8 & $5.08 \pm 0.98$ & 90.0 \\
11.30 & $11.35 \pm 0.72$ & 100.4 & $9.83 \pm 0.76$ & 87.0 \\
28.25 & $25.42 \pm 0.70$ & 89.9 & $24.01 \pm 0.86$ & 84.9 \\
\hline
\end{tabular}

TABLE II - Saturation solubility of quercetin in different media

\begin{tabular}{lc}
\hline Medium & Solubility $(\mu \mathrm{g} / \mathrm{mL})$ \\
\hline $0.15 \mathrm{M}$ phosphate buffer $(\mathrm{pH} 7.2)$ & $0.48 \pm 0.072$ \\
$0.15 \mathrm{M}$ phosphate buffer $(\mathrm{pH} 7.2)+10 \%$ ethanol & $2.40 \pm 0.021$ \\
$0.15 \mathrm{M}$ phosphate buffer $(\mathrm{pH} 7.2)+0.5 \%$ Tween $^{\circledR} 20$ & $27.93 \pm 0.26$ \\
\hline
\end{tabular}


and transdermal delivery of quercetin from different types of vehicles (Bonina et al., 1996; Casagrande et al., 2007).

Therefore, to concentrate and analyze this flavonoid by HPLC, quercetin was extracted from receptor medium (0.15 M phosphate buffer, $\mathrm{pH} 7.2$ plus $0.5 \%$ of Tween ${ }^{\circledR}$ $20)$ by liquid-liquid extraction method. This is a simple method in which a variety of organic solvents can be used and, for this reason, it gives a wide rate of selectivity and solubility (Queiroz et al., 2001).

Three different solvents, which have different polarities, were tested in order to select the one that has the best extractor power for quercetin in the employed conditions. The organic solvent chloroform showed a peak in the same retention time of quercetin, which might be due to impurities of this solvent that were concentrated with the flavonoid during the samples drying process. The second solvent employed was hexane, but this one was not able to extract quercetin from aqueous solution because of its smaller polarity. Dichloromethane, which has intermediate polarity when compared to hexane and chloroform, was the solvent that best extracts quercetin from the receptor medium. The average of recovery for all the different concentrations of quercetin employed was $80 \%$. Nevertheless, to improve these results the $\mathrm{pH}$ of aqueous solution was changed in order to obtain the quercetin in non-ionized form, which will increase its partition to organic portion. Since this flavonoid is insoluble in water, it is difficult to assess its $\mathrm{pKa}$ then it was necessary to evaluate the recovery when applied different $\mathrm{pHs}$ (4.0, 5.0 and 8.6). The first one was the most reproducible and showed an average recovery of $96 \%$ as shown in Table III. Furthermore, the evaluation of the efficiency of the extractor solvent drying procedure showed total recovery of the active quercetin (Table IV).

Then, the results demonstrated that the method developed to extract quercetin from receptor medium, changing the final $\mathrm{pH}$ of this to 4.0 and using dichloromethane as solvent extractor, was sensitive and reproducible since it showed a high recovery of the flavonoid.

At $12 \mathrm{~h}$ post-application of a propylene glycol solution and a w/o microemulsion formulation containing quercetin in the final concentration of $0.3 \%(\mathrm{w} / \mathrm{w}), 9.40$ $\pm 0.57 \mu \mathrm{g} / \mathrm{cm}^{2}(\mathrm{n}=5)$ of quercetin was detected in the SC and $0.13 \pm 0.03 \mu \mathrm{g} / \mathrm{cm}^{2}$ in the $[\mathrm{E}+\mathrm{D}]$ for the first one and $16.94 \pm 0.84 \mu \mathrm{g} / \mathrm{cm}^{2}(\mathrm{n}=5)$ in the SC and $2.51 \pm 0.12 \mu \mathrm{g} /$ $\mathrm{cm}^{2}$ in the $[\mathrm{E}+\mathrm{D}]$ for the microemulsion (Figure 2). No quercetin was detected in the receptor medium. These results demonstrated that the methods developed in the present work were suitable to determine the penetration in different skin layers and percutaneous delivery of quercetin when this was topically applied.

TABLE III - Recovery of the extraction procedure of quercetin from receptor medium (final $\mathrm{pH}=4$ ) using dichloromethane as extractor solvent

\begin{tabular}{ccc}
\hline Real concentration $(\mu \mathrm{g} / \mathrm{mL})$ & $\begin{array}{c}\text { Obtained concentration }(\text { mean } \pm \mathrm{SD}) \\
(\mu \mathrm{g} / \mathrm{mL})\end{array}$ & Recovery $(\%)$ \\
\hline 0.05 & $0.056 \pm 0.009$ & 112.0 \\
0.10 & $0.08 \pm 0.01$ & 80.0 \\
0.50 & $0.48 \pm 0.06$ & 96.0 \\
1.0 & $1.03 \pm 0.18$ & 103.2 \\
2.0 & $1.97 \pm 0.12$ & 98.5 \\
5.0 & $4.55 \pm 0.88$ & 91.0 \\
\hline
\end{tabular}

TABLE IV - Recovery of quercetin after the drying procedure of the extractor solvent

\begin{tabular}{ccc}
\hline Real concentration $(\mu \mathrm{g} / \mathrm{mL})$ & $\begin{array}{c}\text { Obtained concentration }(\text { mean } \pm \mathrm{SD}) \\
(\mu \mathrm{g} / \mathrm{mL})\end{array}$ & Recovery $(\%)$ \\
\hline 0.05 & $0.059 \pm 0.10$ & 118.0 \\
0.10 & $0.09 \pm 0.05$ & 90.0 \\
0.50 & $0.51 \pm 0.09$ & 102.0 \\
1.0 & $1.00 \pm 0.25$ & 100.0 \\
2.0 & $2.05 \pm 0.13$ & 102.5 \\
5.0 & $4.90 \pm 0.90$ & 98.0 \\
\hline
\end{tabular}




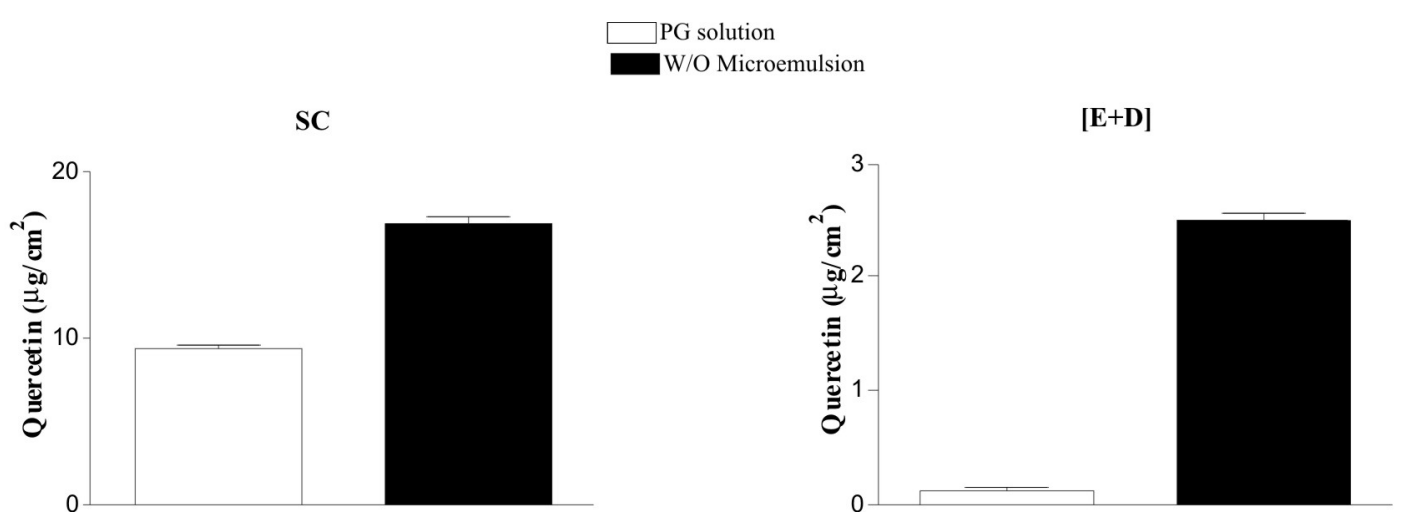

FIGURE 2 - In vitro quercetin penetration in the stratum corneum (SC) and in the epidermis plus dermis ([E+D]) after 12 hours post-application of a propylene glycol (PG) solution and w/o microemulsion, both containing quercetin $(0.3 \%$, w/w).

\section{CONCLUSION}

The combined procedures of extraction and DPPH $•$ assay of quercetin in the SC and HPLC assay of quercetin in $[E+D]$ and in receptor phase are efficient in terms of drug recovery and rapid manipulation. Furthermore, considering the therapeutic advantages of topical administration of quercetin to control UVB-induced oxidative damages, the proposed methodologies for quercetin assay in samples of different skin layers and in receptor medium, from in vitro and even in vivo studies, could be very important in the design and evaluation of topical and transdermal drug delivery.

\section{ACKNOWLEDGMENTS}

The authors are grateful to Dr. Luciana B. Lopes for helpful discussions. This work was supported by "Coordenação de Aperfeiçoamento de Pessoal de Nível Superior" (CAPES, Brazil) and "Fundação de Amparo à Pesquisa do Estado de São Paulo” (FAPESP, Brazil).

\section{REFERENCES}

BLOIS, M.S. Antioxidant determinations by use of a stable free radical. Nature, London, v.181, p.1199-1200, 1958.

BONINA, F.; LANZA, M.; MONTENEGRO, L.; PUGLISI, C.; TOMAINO, A.; TROMBETTA, D.; CASTELLI, F.; SAIJA, A. Flavonoids as potential protective agents against photo-oxidative skin damage. Int. J. Pharm., Amsterdam, v.145, p.87-94, 1996.
BOUDJELAL, M.; WANG, Z.; VOORHEES, J.J.; FISHER, G.J. Ubiquitin/proteasome pathway regulates levels of retinoic acid receptor gamma and retinoid $\mathrm{X}$ receptor alpha in human keratinocytes. Cancer Res., Baltimore, v.60, p.2247-2252, 2000.

CARERI, M.; ELVIRI, L.; MANGIA, A.; MUSCI, M. Spectrophotometric and coulometric detection in the highperformance liquid chromatography of flavonoids and optimization of sample treatment for the determination of quercetin in orange juice. J. Chromatogr. A, Amsterdam, v.881, p.449-460, 2000.

CASAGRANDE, R.; GEORGETTI, S.R.; VERRI JR, W.A.; BORIN, M.F.; LOPEZ, R.F.V.; FONSECA, M.J.V. In vitro evaluation of quercetin cutaneous absorption from topical formulations and its functional stability by antioxidant activity. Int. J. Pharm., Amsterdam, v.328, p.183-190, 2007.

CASAGRANDE, R.; GEORGETTI, S.R.; VERRI JR, W.A.; DORTA, D.J.; dos SANTOS, A.C.; FONSECA, M.J.V. Protective effect of topical formulations containing quercetin against UVB-induced oxidative stress in hairless mice. J. Photochem. Photobiol. B, Lausanne, v.84, p.2127, 2006a.

CASAGRANDE, R.; GEORGETTI, S.R.; VERRI JR, W.A.; JABOR, J.R.; SANTOS, A.C.; FONSECA, M.J.V. Evaluation of functional stability of quercetin as a raw material and in different topical formulations by its antilipoperoxidative activity. AAPS PharmSci. [serial online], Arlington, v.7, p.E1-E8, 2006b. 
DINIS, T.C.P.; MADEIRA, V.M.C.; ALMEIDA, L.M. Action of phenolic derivates (acetaminophen, salicylate, and 5-aminosalicylate) as inhibitors of membrane lipid peroxidation and as peroxyl radical scavengers. Arch. Biochem. Biophys., New York, v.315, p.161-169, 1994.

GEORGETTI, S.R.; CASAGRANDE, R.; DI MAMBRO, V.M.; AZZOLINI, A.E.C.S.; FONSECA, M.J.V. Evaluation of the antioxidant activity of different flavonoids by the chemiluminescence method. AAPS PharmSci. [serial online], Arlington, v.5, p.1-5, 2003.

LOPES, L.B.; BENTLEY, M.V.L.B. Cyclosporin A in skin samples from in vitro penetration studies may be assayed by a simple HPLC method. Rev. Bras. Ciênc. Farm., São Paulo, v.41, p.477-482, 2005.

MOSER, K.; KRIWET, K.; NAIK, A.; KALIA, Y.N.; GUY, R.H. Passive skin penetration enhancement and its quantification in vitro. Eur. J. Pharm. Biopharm., Stuttgart, v.52, p.103112, 2001.

NUUTILA, A.M.; PUUPPONEN-PIMIÄ, R.; AARNI, M.; OKSMAN-CALDENTEY, K.-M. Comparison of antioxidant activities of onion and garlic extracts by inhibition of lipid peroxidation and radical scavenging activity. Food Chem., Barking, v.81, p.485-493, 2003.

PINELO, M.; MANZOCCO, L.; NUÑEZ, M.J.; NICOLI, M.C. Solvent effect on quercetin antioxidant capacity. Food Chem., Barking, v.88, p.201-207, 2004.

PODDA, M.; TRABER, M.G.; WEBER, C.; YAN, L.J.; PACKER, L. UV-irradiation depletes antioxidants and causes oxidative damage in model of human skin. Free Radic. Biol. Med., New York, v.24, p.55-65, 1998.

QUEIROZ, S.C.N.; COLLINS, C.H.; JARDIM, I.C.S.F. Métodos de extração e/ou concentração de compostos encontrados em fluídos biológicos para posterior determinação cromatográfica. Quim. Nova, São Paulo, v.24, p.68-76, 2001.
RÖPKE, C.D.; KANEKO, T.M.; RODRIGUES, R.M.; SILVA, V.V.; BARROS, S.; SAWADA, T.C.H.; KATO, M.J.; BARROS, S.B.M. Evaluation of percutaneous absorption of 4-nerolidylcathecol from four topical formulations. Int. J. Pharm., Amsterdam, v. 249, p.109-116, 2002.

SAIJA, A.; TOMAINO, A.; TROMBETTA, D.; GIACCHI, M.; DE PASQUALE, A.; BONINA, F. Influence of different penetration enhancers on in vitro skin permeation and in vivo photoprotective effect of flavonoids. Int. J. Pharm., Amsterdam, v.175, p.85-94, 1998.

SILVA, M.M.; SANTOS, M.R.; CAROÇO, G.; ROCHA, R.; JUSTINO, G.; MIRA, L. Structure-antioxidant activity relationships of flavonoids: a re-examination. Free Radic. Res., London, v.36, p.1219-1227, 2002.

TSIMOGIANNIS, D.I.; OREOPOULOU, V. Free radical scavenging and antioxidant activity of 5,7,3, 4 ' - hydroxysubstituted flavonoids. Innovat. Food Sci. Emerg. Tech., Berlin, v.5, p.523-528, 2004.

VICENTINI, F.T.M.C.; CASAGRANDE, R.; GEORGETTI, S.R.; BENTLEY, M.V.L.B.; FONSECA, M.J.V. Influence of vehicle on antioxidant activity of quercetin: a liquid crystalline formulation. Lat. Am. J. Pharm., Buenos Aires, v.26, p.805-810, 2007a.

VICENTINI, F.T.M.C.; GEORGETTI, S.R.; JABOR, J.R.; CARIS, J.A.; BENTLEY, M.V.L.B.; FONSECA, M.J.V. Photostability of quercetin under exposure to UV irradiation. Lat. Am. J. Pharm., Buenos Aires, v.26, p.119124, 2007b.

XU, Y.; FISHER, G.J. Ultraviolet (UV) light irradiation induced signal transduction in skin photoaging. J. Dermatol. Sci. Suppl., New York, v.1, p.S1-S8, 2005.

Received for publication on $05^{\text {th }}$ december 2008 Accepted for publication on $29^{\text {th }}$ january 2009 